\title{
Modeling and Development of a Methodology for Assessing the Socio-Economic Processes in the Management of Innovative Infrastructure
}

\author{
Sergey Mikhailovich Vasin \\ Leyla Ayvarovna Gamidullaeva
}

Penza State University, Russia, 440026, Penza, Krasnaya Street, 40

\section{Doi:10.5901/mjss.2015.v6n3p212}

\section{Abstract}

\begin{abstract}
The aim of our studies was to develop recommendations to management representatives of business incubators concerning its management structures, as well as to the public authorities in charge of regulation of this sphere. In this article a methodology for assessing the socio-economic processes of business incubation was developed ;it differs from the previously proposed by foreign and Russian scientists systematic approach to the consideration of the management of the business incubator and the ability to quantify the level of development of management processes, which allows to identify and calculate the available socio-economic resources in their development. This article includes first proposed models describing the effect of management processes of business incubators on their effectiveness (a model showing the influence of the process of establishing criteria for selecting businesses on the number of jobs created in the business incubator; a model illustrating the effect of the process of formation and use of sources on financing on the financial profitability of the business incubator, and so on). The use of these models in the practice of management of business incubators might give the opportunity to consider the influence of qualitative factors (the goal of business incubation, the quality of services provided; qualification of personnel, etc.) in the assessment of business incubators as a socio-economic systems. Results of the study are universal and can be used as a methodological tool for improving the management of any business incubators.
\end{abstract}

Keywords: Innovative Infrastructure; business incubation; socio-economic processes; modeling; management b usiness incubator.

\section{Introduction}

Intellectual capital is becoming one of the key resources, the use of which is a source of innovation. L.A. Anosova, giving the definition of the term "innovation" writes the following: "it means materialized latest scientific and technical ideas. When they receive recognition in the market of consumers, they, along with the science are considered in the context of globalization as the foundation, and in addition to this as a tool to improve competitiveness and security, as well as a basic element of a new type of society, the development of which is based on knowledge (Anosova, 2010).

As it was noted in the annual message to the Federal Assembly of the Russian President, in recent years, Russia has achieved much, but in the coming years we have to be able to solve a whole range of complex urgent national problems, among which were mentioned modernization of the economy and its transfer to an innovative way of development, improving governance, and others. The political orientation of these areas has been identified and proposed in the "Strategy of socio-economic development of Russia until 2020" (2).

A necessary condition for the implementation of the given objectives is to intensify the processes of scientific and technological renovation of the economy, the introduction of adequate, relevant production technologies which meet modern times requirements in all sectors and industries.

It is well known that Russia's economy is dominated by mostly morally and physically obsolete fixed foundations, which consequently hinder the development and introduction of new production technologies. This contrariety leads to technical and technological gap between foreign manufacturers of high technology products.

According to international ratings of innovative activity and the competitiveness - their level in the Russian Federation is extremely low (Table. 1). 
Table 1 - International ratings of innovative activity and competitiveness of some countries by the method of INSEAD, $B C G$ and $G C I$ WEF *

\begin{tabular}{|l|c|c|c|c|c|c|}
\hline & \multicolumn{3}{|c|}{\begin{tabular}{c} 
Global Innovation Index INSEAD, \\
\cline { 2 - 7 }
\end{tabular}} & $\begin{array}{c}\text { Global Innovation Index BCG, } \\
2013\end{array}$ & $\begin{array}{c}\text { The Global Competitiveness Index WEF } \\
2013-2014\end{array}$ \\
\cline { 2 - 7 } & The total score & Rating & The total score & Rating & The total score & Rating \\
\hline Switzerland & 66,6 & 1 & 2,23 & 3 & 5,67 & 1 \\
\hline Sweden & 61,4 & 2 & 1,64 & 10 & 5,48 & 6 \\
\hline UK & 61,2 & 3 & 1,42 & 15 & 5,37 & 10 \\
\hline Netherlands & 61,1 & 4 & 1,55 & 12 & 5,42 & 8 \\
\hline USA & 60,3 & 5 & 1,80 & 8 & 5,48 & 5 \\
\hline Finland & 59,5 & 6 & 1,87 & 7 & 5,54 & 3 \\
\hline Hong Kong & 59,4 & 7 & 1,88 & 6 & 5,47 & 2 \\
\hline Singapore & 59,4 & 8 & 2,45 & 1 & 5,61 & 64 \\
\hline Russia & 37,2 & 62 & $-0,09$ & 49 & 4,25 & \\
\hline
\end{tabular}

* Compiled by the authors using sources $(3 ; 4 ; 5)$.

This can be explained by the fact that many business organizations, which form the basis of economic system in every developed country in the world, over a long period do not have the necessary investment and suitable innovation providing.

International and domestic experience prove that without the existence and activity of many small businesses market cannot be developed. Small businesses are created and liquidated. Their emergence and development create a kind of "movement" being is a necessary link, without which no energy of interaction of various components of the market is transferred.

Small businesses are a stimulant to create a high level of competition in the market for goods and services, resulting in improved product quality and higher standards of living. Eventually, they form the middle class, which is considered to be the basis for the stability of any society (Gamidullaeva, 2013).

Effective means of reducing failures in business, increasing the share of surviving businesses are business incubators - a type of specialized infrastructure facilities to support small business, along with foundations, business centers, educational, informational and other service structures (Shamray, 2005).

The term of "business-incubator" means the socio-economic system, the functioning of which is aimed at supporting small businesses by providing a comprehensive set of services (accounting, legal, consulting, information, etc.), as well as the promotion of their business (Gamidullaeva, 2009).

Overseas experience shows that for the successful development of business incubation, a significant attention of state and local authorities is vitally important. Business incubator is not an organization that brings immediate returns (except for social). The return on investment comes from firms, grown in a business incubator, and the period of formation of firms is typically 3-4 years. Without significant financial investments and other financial assistance to implement it is quite difficult the technology of business incubation.

It is not surprising that the development of business incubators is the focus of the governments attention in different countries

Support for small businesses based on business incubation is considered a strategic perspective as the most important factor of social and economic development of the Russian Federation. Regarding this the problem of increasing the efficiency of business incubators deserves special attention.

Questions to the management of business incubators as socio-economic systems are insufficiently studied and highlighted in scientific papers (Aaboen, 2009; Bergek and Norrman, 2008; Chen, 2009; Kemp, 2011; Lilai, 2010; etc.). The topic of the systematic approach to the management of social and economic processes of business incubation is not covered, as well as methods of evaluating the management processes and results of operation of business incubators.

\section{Methods}

Business incubation in Russia has passed a certain path of development, but has not yet become effective functioning sector of the economy.

The main problems faced by the business incubator in the Russian economy has been attributed as follows (MGIMO, 2012): low entrepreneurial activity (32\%), difficulty in finding partners and sponsors (30\%), lack of experience in the business incubation and poor infrastructure in business incubation (17\%), poor infrastructure in the region (20\%), lack 
of support from authorities (15\%).

In the study of the problem of improving the efficiency of business incubators authors have developed a method of estimating the management data of socio-economic systems.

All quantitative calculations in this article are based on data obtained from the study of 12 business incubators from different regions of the Russian Federation: Krasnoyarsk region, Moscow Region, Republic of Mordovia, Penza region, Nizhny Novgorod region, Omsk, Vologda, Kurgan Oblast, Saratov Oblast, the Republic of Tatarstan, Rostov and Novosibirsk regions.

The key task of effective management shall consist in the formation, implementation and use of a comprehensive performance management system based on the projected and current changes in the internal environment, as well as the impacts of external changes (Vasin, 2012).

System for managing business incubators can be characterized by a set of quantitative and qualitative indicators, though their degree of influence on the results of business incubators is often underestimated.

The evaluation of these parameters is of great significance, since it is possible to determine the basis of the reserves in the management and improve the management of business incubators.

Formation of indicators` aggregate for assessing management business incubators has been performed according to the following principles:

1. Each of the subsystems of the system of business incubators should be fully covered by indicators.

2. Within each subsystem indicators that reflect the sequence of management actions shall be designed.

3. When calculating the indicators it is necessary to combine (if possible) several analytical techniques that help to reflect the actual and the desired state of a management event.

4. Efficiency indicators should be calculated with the greatest possible accuracy.

In this study, the following indicators to measure a variety of activities in the management of business incubators were developed: the planning of activities in the process of incubating firms as well.

Approaches to the calculation of indicators that reflect the level of any management activities are slightly different depending on the research methods used in the analysis of specific activities.

Calculation of the first group of indicators is the result of a combination of several methods, which includes the method of questioning and the expert-analytical one. The scale of assessment of an indicator in this case is formulated to carry out a comparison of estimates of actual use criteria, directions and other methodological components of the system of business incubators and their expected effectiveness, the importance from the viewpoint of business executives and government agencies (as determined by the results of the expert survey). Criterion or method was evaluated in fractions of a unit in the range from 0 to 1 , with a gradation into six main states: a complete lack or insignificance of a certain criterion $(0)$, a very small degree of use or efficiency $(0-0.2)$, rather insignificant level $(0,21-0.4)$, the average level $(0.41-0.6)$, greater level $(0.61-0.8)$, a very high level $(0.81-1.0)$ of the actual application and effectiveness.

To calculate the value of expert indicators we used the method of the expert survey. The qualitative composition of experts formed the executives of large, medium and small businesses, as well as government representatives.

The number of experts corresponds to a small sample of experts Students. The average coefficient of awareness experts is 0.72 . The average coefficient of reasoning for all experts is 0.85 , which indicates a high degree of reasoning. Level of competence of the expert group was 0.785 , which corresponds to an above - average level.

The second group of indicators is calculated on the basis of evidence obtained as a result of a questionnaire addressed to managers and internal clients business incubators. Indicators in this group are totals that characterize performance of business incubators: the number of jobs created per tenant (MRC); the survival rate of businesses after leaving the business incubator (CB); financial profitability of the business incubator (RF).

Thus, the indicator of the effectiveness of using a set of services is calculated as follows:

$\Pi_{y c r}=\sum U_{s}^{*} I_{a s s}(1)$,

where $U_{s}$ - the actual use of each service (on the scale);

$I_{\text {ass }}$ - expert assessment of the importance (on the scale).

Similarly, we calculated performance indicators of the use of information dissemination channels about business incubators, service quality, relationship with the staff of tenants of the business incubator, working conditions, the use of sources of funding business incubators and others.

Comparing the maximum level of a particular indicator to its actual value, calculated on the basis of information on certain activities of the business incubator, we can draw conclusions about the level of control of various processes of business incubation. 
An example of such comparison is presented in the following comparison chart illustrating the performance of using a set of services among the business incubators and the maximum possible value (see Fig. 1).

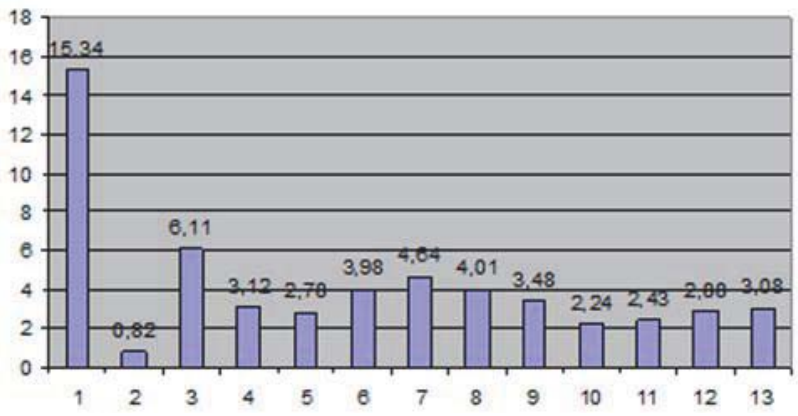

1 - maximum

2-13 - business incubators of the aggregate sample.

Figure 1. Levels of performance indicator using a set of services

Due to the fact that the calculated figures reflect the quantitative evaluation of the management value processes of business incubators, it is possible to determine the most significant management measures to improve the system of business incubation.

In fact, almost every indicator can calculate some limiting value, which theoretically can be achieved with constant use of the criteria areas, sources that are used in the calculation of each indicator.

This work includes the analysis of the influence of individual indicators concerning management business incubators at some of the results of business incubators using correlation and regression analysis method.

Models of discovered dependencies are linear and represent equations of the line:

$y=A_{0}+A_{1} X(2)$,

where $y$ - a resultative indication or a dependent variable;

$X-a$ factorial indication or an independent variable;

$A_{0}$-a conditional value of resultant variable at the zero value factor variable;

$A_{1}$ - a parameter of the equation (point approximation, i.e. the approximation function).

To quantify the closeness of the connection between the indicators, the correlation coefficient $r$ is used. It is defined by the formula:

$r=\frac{\sum X y-\left(\sum X \sum y / n\right)}{\sqrt{\left(X^{2}-X^{2} / n\right)} \sqrt{\left(\sum y^{2}-y^{2} / n\right.}}$

where $\mathrm{n}$ - the number of objects of the study.

Qualitative assessment of closeness of the connection by using the scale of Čedok (Table 2).

Table 2 - The scale of Čedok

\begin{tabular}{|l|c|c|c|c|c|c|}
\hline Indicator of the closeness of the connection & $0,1-0,3$ & $0,3-0,5$ & $0,5-0,7$ & $0,7-0,8$ & $0,9-0,99$ & 1 \\
\hline The characteristic of connection & weak & moderate & noticeable & tight & Very tight & functional \\
\hline
\end{tabular}

The significance of the coefficient which was found can be checked by the criterion for significance using Student's criterion, the estimated value of which is determined by the formula:

$$
S_{p}=R \sqrt{\frac{n-2}{1+r^{2}}}
$$

The resulting value is compared with the tabulated value at $P=0.95$. The excess of the estimated value of the table shows the significance of the coefficient found.

The algorithm of the application of this technique can be seen in the example of calculation of performance indicators using a set of services. 
The study found that incubators have a very small range of services, apart from providing space for rent. Last service is provided by all incubators. The most frequently provided services consist of helping in the registration process, technical services, Internet services, less likely - accounting services and assistance in the preparation of the business plan (see Fig.1)

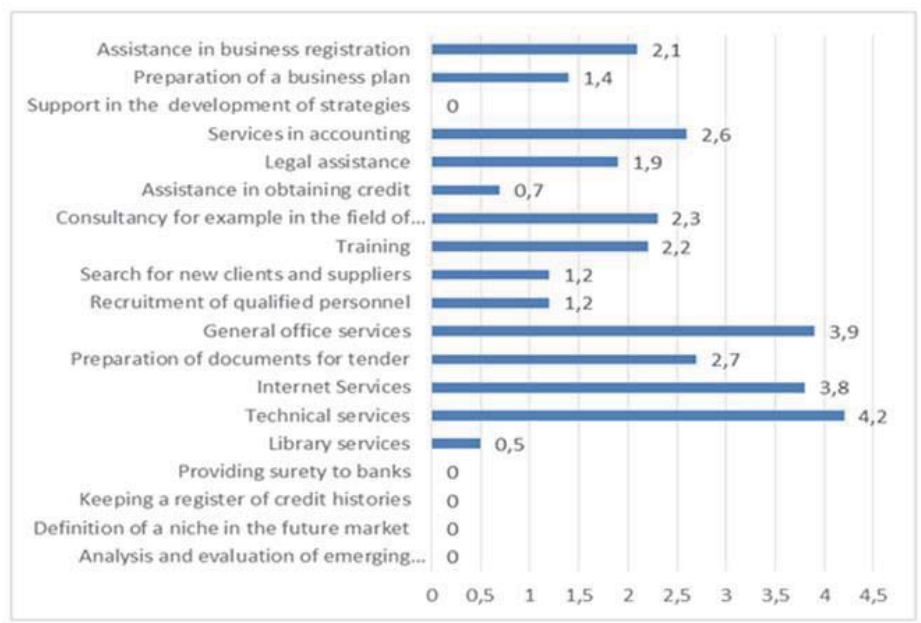

Figure 2: Average estimates of the frequency of services business incubators

However, experts have identified some very important services, which are generally absent in business incubators. Experts have mentioned as important ( in the range from 0.8 to 1 ) services such as the provision of a guarantee to the banks, keeping a register of the credit history, the definition of a niche market in the future, analysis and evaluation of emerging companies, business plan preparation, support the development of strategies and assistance in obtaining credit, legal assistance and general office services.

Calculating the efficiency indicator obtained from the set of services, we have the opportunity to compare them with each other and with the greatest possible value. The maximum value in this case, is the sum of importance identified by experts for all kinds of services, and it is equal 15.34. (Fig. 3).

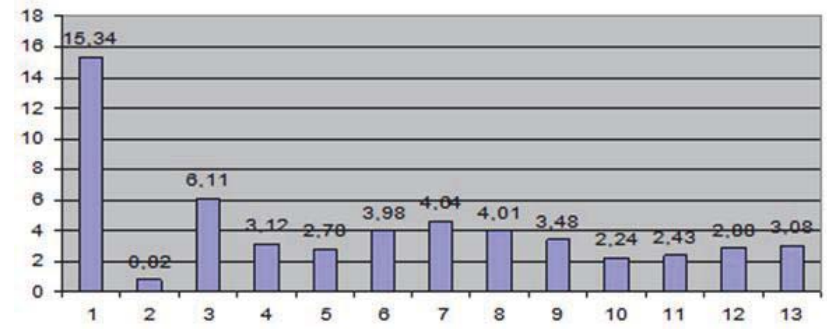

1 - maximum

2-13 - business incubators of the total sample

Figure 3: Levels of performance indicator obtained from the set of services.

Thus, clearly shows that the indicators of incubators lag behind the maximum possible value of this indicator, provided the provision of all kinds of services to the maximum extent.

We carried out a correlation analysis which showed an association between the ratio of the effective use of services and the number of created jobs in the incubator. The correlation coefficient was 0.8196 , therefore, the association is considered as strong. Student criterion at the confidence level $\mathrm{P}=0.95$ exceeded the table value and was equal to 4.5 , indicating the significance of the coefficient. 
Regression model under these conditions is as follows:

$y=2,732 x-1,016$,

where $x$ - indicator of the effectiveness of using a set of services; $y$ - number of jobs created per tenant.

Correlation analysis revealed an association of this indicator with the value of the exponent of the survival of enterprises. The correlation coefficient was 0.6675 , indicating no significant associations. Student criterion which was 2.84 exceeded the table value, thus it confirms the significance of the coefficient found.

Descriptive model that reflects the relationship between performance, takes the form:

$y=0,08 x+0,339$,

where $x$ - indicator of the effectiveness of using a set of services by business incubators; $y$ - the survival rate of businesses.

The analysis revealed the dependence of this parameter on the value of financial profitability of incubators. The correlation coefficient was 0.8309 , therefore, it is considered as strong. Student criterion 4.73 confirmed the importance of this factor.

Regression model thus is as follows:

$y=0,146 x+0,3$

where $x$ - indicator of the effectiveness of using a set of services; $y$ - financial profitability of business incubators.

In this study, were also drawn up a model reflecting the relationship between other indicators of assess of the socio-economic processes management business incubators and their outcome indicators.

\section{Results}

Detailed results of the analysis are presented in Table 3. The proposed method has been tested in a business incubator "Penza regional center to promote innovation" (Penza). Its implementation contributed to the growth of effective indicators of the business incubator.

Table 3 - The tightness of correlation between the original and the total activity of the business incubator

\begin{tabular}{|c|c|c|c|c|c|c|c|c|c|c|c|c|c|c|c|}
\hline \multirow{3}{*}{ Input indicators } & \multicolumn{15}{|c|}{ The correlation coefficients $\left(r_{y x}\right)$, determination $\left(r_{y x}^{2}\right)$, significance for Student t-test of the correlation coefficient $(\xi)$} \\
\hline & \multicolumn{5}{|c|}{ Quantity of jobs per 1 tenant } & \multicolumn{5}{|c|}{$\begin{array}{c}\text { The survival rate of enterprises after leaving } \\
\text { the incubator }\end{array}$} & \multicolumn{5}{|c|}{$\begin{array}{c}\text { Financial profitability } \\
\text { incubator }\end{array}$} \\
\hline & $r_{y x}$ & $\begin{array}{c}\text { measures of } \\
\text { association }\end{array}$ & \begin{tabular}{l|l|} 
& $r^{2} y x$ \\
\end{tabular} & $\xi$ & $\begin{array}{c}\text { significance } \\
r_{y}\end{array}$ & $r_{y x}$ & $\begin{array}{c}\text { Measures of } \\
\text { association }\end{array}$ & $r^{2} y x$ & $\xi$ & $\begin{array}{c}\text { significance } \\
r_{y}\end{array}$ & $r_{y x}$ & \begin{tabular}{|c|} 
measures of \\
association
\end{tabular} & $r^{2} y x$ & $\xi$ & $\begin{array}{c}\text { significance } \\
r_{y}\end{array}$ \\
\hline $\begin{array}{l}\text { The effectiveness of the use } \\
\text { of distribution channels for } \\
\text { business incubator }\end{array}$ & 0,8456 & Strong & 0,72 & 5,01 & signif. & 0,3851 & Modest & 0,15 & 1,32 & Insignif. & 0,5205 & Modest & 0,27 & 1,93 & Insignif. \\
\hline $\begin{array}{l}\text { The effectiveness of the use } \\
\text { of measures to raise public } \\
\text { awareness about the } \\
\text { business incubation }\end{array}$ & 0,7611 & Strong & 0,58 & 3,71 & signif. & 0,5500 & Modest & 0,30 & 2,08 & Insignif. & 0,6911 & Modest & 0,48 & 3,02 & Signif. \\
\hline $\begin{array}{l}\text { The significance of the } \\
\text { objectives of business } \\
\text { incubation }\end{array}$ & 0,7597 & Strong & 0,58 & 3,69 & signif. & 0,7169 & Strong & 0,51 & 3,25 & signif. & 0,7133 & Strong & 0,51 & 3,22 & Signif. \\
\hline $\begin{array}{l}\text { The effectiveness of using a } \\
\text { set of services }\end{array}$ & 0,8196 & Strong & 0,67 & 4,52 & signif. & 0,6675 & Modest & 0,45 & 2,84 & signif. & 0,8309 & Strong & 0,69 & 4,73 & Signif. \\
\hline $\begin{array}{l}\text { The significance of the } \\
\text { criteria for selection of } \\
\text { companies to the incubator }\end{array}$ & 0,7784 & Strong & 0,61 & 3,92 & signif.. & 0,5467 & Modest & 0,30 & 2,06 & Insignif. & 0,8859 & Strong & 0,78 & 5,97 & Signif. \\
\hline Quality of services & 0,7184 & Strong & 0,52 & 3,26 & signif. & 0,784 & Strong & 0,61 & 4,00 & signif. & 0,366 & Weak & 0,13 & 1,20 & Insignif. \\
\hline $\begin{array}{l}\text { Customer relationship with } \\
\text { the staff of the business } \\
\text { incubator }\end{array}$ & 0,7551 & Strong & 0,57 & 3,65 & signif. & 0,6433 & Strong & 0,41 & 2,7 & signif. & 0,7516 & Strong & 0,56 & 3,60 & Signif. \\
\hline equipment status & 0,3826 & Moderate & 0,15 & 1,33 & Insignif. & 0,4034 & Moderate & 0,16 & 1,40 & Insignif. & 0,5963 & Modest & 0,36 & 2,30 & Signif. \\
\hline $\begin{array}{l}\text { Conditions of work in the } \\
\text { business incubator }\end{array}$ & 0,7930 & Strong & 0,63 & 4,1 & signif. & 0,6524 & Замет. & 0,43 & 2,7 & Signif. & 0,5282 & Modest & 0,28 & 1,97 & Insignif \\
\hline $\begin{array}{l}\text { Qualification of the incubator } \\
\text { s staff }\end{array}$ & 0,6027 & Modest & 0,36 & 2,38 & signif. & 0,7081 & Strong & 0,87 & 3,17 & signif. & 0,4492 & Moderate & 0,20 & 1,59 & Insignif \\
\hline $\begin{array}{l}\text { The effectiveness of the use } \\
\text { of sources of financing of the } \\
\text { business incubator }\end{array}$ & 0,9086 & Very strong & 0,83 & 6,90 & signif. & 0,238 & Weak & 0,06 & 0,78 & Insignif. & 0,8893 & Strong & 0,79 & 6,15 & Signif. \\
\hline
\end{tabular}


The obtained results allow us to optimize and improve the activities of business incubators. As an example, we consider the general scheme which offers advice to management of business incubators basing on such a socio-economic process of business incubation, as the provision of an optimal set of high-quality services. This element needs to be considered in two aspects:

1. optimal range of services offered;

2. quality of service.

Indicator of the effectiveness of using a set of services serves to evaluate if the set of services is well-formed and to identify the scope for optimizing the management in this regard.

This is the process of improving the use of a set of services represented in general form (see Fig. 4).

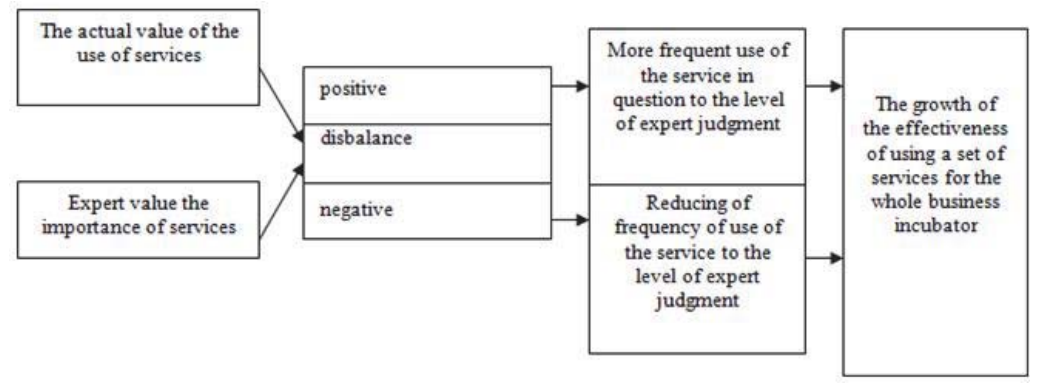

Figure 4: Diagram of improving the use of a set of services

Another aspect in this element is the quality of delivery service. Rationalization of managementin this case is associated with bringing the actual level of the index to the level recommended by experts.

Analysis of the elements of the functional components of the system of business incubators suggests the divergence of the actual situation with its desired level.

Effective management of such entities as business incubators allows to realize the significant opportunities available to them. We conducted a study of the functional components or subsystems in the overall system for managing business incubators, such as, firstly, the planning of a business incubator, and secondly, the process of business incubation itself and, thirdly, the quality control. Each of these components includes elements which can improve performance of all of the incubator if effectively controlled.

We have derived indicators to measure the main components of the subsystem. Conditions of the most of the proposed indicators have a significant impact on the effectiveness of the business incubator. Thus, managers of business incubators can affect them intentionally to improve the efficiency of the organization. As for the other indicators, we suggest managers to use expert opinion to justify management decision-making. This will, in our view, optimize the management of business incubators.

\section{Discussion}

Having determined the key factors which have the greatest impact on the effectiveness of a business incubator as a socio-economic system, we obtained a possibility of rational distribution of resources for its operation and development.

Identified dependence needs to be periodically corrected, that is not particularly difficult.

Proposed by some authors methods (Dibraeva, 2011; Lalkaka, 2003; Monastirskiy, 2009; Tormysheva, 2012; Shestov, 2013; Dee et al, 2012; etc.), do not have differences in a systematic approach to the consideration of the management of a business incubator. Our proposed technique provides the ability to quantify the level of development of management processes, which allows to identify and calculate the available socio-economic resources in their development.

This study presents a model describing the effect of management process of business incubators on their effectiveness (model influence the process of establishing criteria for selecting businesses to the number of jobs created in the business incubator model of the effect of the process of formation and use of sources of financing on the financial profitability of the business incubator etc.). The use of models in the practice of management of business incubators gives the opportunity to consider the influence of qualitative factors (the goal of business incubation, the quality of services 
provided; qualification of personnel, etc.) in the assessment of business incubators as a socio-economic system. The proposed dependences are universal and can be used in the practice of management in any business incubator.

Promoted by a number of researchers to evaluate the effectiveness of business incubator system KPI, in our opinion, does not allow to take into account the current socio-economic processes of business incubation in the dynamics, as well as to identify existing reserves of development.

Thus, the use of our proposed methodology for assessing the effectiveness of business incubators in Russia is essential in contemporary conditions, as it will allow a comprehensive approach to the evaluation of the data structures and taking management decisions, and as a consequence, increase the effectiveness of their work in the form of higher socio-economic performance evaluation of their activities.

\section{Conclusions}

This research has allowed to disclose reserves in the management of business incubators and improve management activities in order to improve the impact of their activities as socio-economic systems.

The conclusion that follows from the results of the study allows management authorities to focus on the specific socio-economic processes of management of business incubators, but it doesn't mean ignoring the other indicators because only integrated management will ensure the maximum efficiency.

The study developed a method that has the following characteristics:

First, it provides an opportunity to review the business incubator as a socio-economic system and the usage of the many factors that can later be supplemented;

Secondly, the technique allows not only to determine the level of particular indicators characterizing the efficiency of socio-economic processes of business incubation, but also to identify existing reserves of development to define key factors that have the greatest impact on the effectiveness of business incubators, and compare objects of research between themselves.

However, the presented method is limited by a number of conditions of its application in practice.

1. Set of factors such as input and output, and moreover their importance will vary depending on the territorial entity where the analysis is carried out. Each region has its own core competencies, reflecting the potential of its territory (Vasin, 2009).

2. Set the original data should be sufficient for finding the significant coefficients and identifying patterns.

3. Found patterns should be stable enough for a certain period of time.

As promising directions for further research we suggest to develop forecasts of the development of business incubators based on the proposed mathematical models that reflect the influence of factors on productive performance of the business incubators, but only in the medium term. In this case, it should be noted that the transfer of patterns of correlation, measured and varying aggregate, from static to dynamics is not, frankly speaking, correct, and requires checking conditions for the admissibility of such a transfer (extrapolation) that goes beyond the statistics (Eliseeva and Yuzbashev, 1995).

\section{References}

Anosova, L.A. (2010). Problems of Russia's transition to innovative development. Economics and management, 10, 25-29.

The strategy of long-term socio-economic development of the Russian Federation for the period until 2020. Legal reference system "Consultant Plus", Russia. Retrieved from http://www.consultant.rul

The Business School for the World (INSEAD). (2014). Retrieved from http://www.globalinnovationindex.org

The Global Innovation Index by the Boston Consulting Group (2014). Retrieved from http://www.bcg.com.

World Economic Forum. (2014). The Global Competitiveness Report 2013-2014. Retrieved from http://www.weforum.org/issues/globalcompetitiveness.

Gamidullaeva, L.A. (2013). Experience the state support of business incubation abroad and its adaptability in Russia. News of the Tomsk State University, 369, 122-125.

Shamray, A.A. (2005). Analysis of the state of innovation infrastructure in the city of Moscow and the development of proposals for the improvement of its operations. Moscow, M.: NISIPP.

Gamidullaeva, L.A. (2009). Development of models for the description and control problems of a business incubator as a socio-economic system. Penza State University of Architecture and Construction. Penza, Russia.

Annual report of business incubator MGIMO. (2012). Retrieved from http://bi.mgimo.ru/public/bimgimo_annual_report-2012.pdf

Vasin, S.M. (2012). The nature and essence of the concept of efficiency of enterprise management system. Vector science of Togliatti State University, 2 (44), 229-233.

Dibraeva, A.S. (2011). Development of the system of business incubators in the innovation economy. St. Petersburg Trade and 
Economic Institute. St. Petersburg, Russia.

Lalkaka, R. (2003). Business incubators in developing countries: characteristics and results of operations. International Journal of Entrepreneurship and innovative management, 1(2), 31-55.

Monastirskiy, E.A., Pushkarenko, A.V., Chistyakova, N.O. (2009). Methodological approaches to evaluating operations innovation system infrastructure in the region. Innovation, 6, 75-81.

Tormysheva, T.A. (2012). Evaluation of the effectiveness of a business incubator. Creative economy, 7 (57), 66-70.

Shestov, A.G. (2013). Questions to evaluate the effectiveness of a business incubator in the match between the analysis and evaluation of innovative structures. Naukovedenie, 4. Retrieved from http://www. naukovedenie.ru/PDF/09evn413.pdf

Vasin, S.M. (2009). Problems of regional transformation in Russia. News of Penza State University named V.G. Belinsky, 12 (16), $52-55$.

Eliseeva, I.I., Yuzbashev, M.M. (1995). The general theory of statistics. Moscow. M.: Finance and statistics.

Dee, N., Gill D., Lacher R., Livesey F., Minshall T. (2012). A review of research on the role and effectiveness of business incubation for high-growth start-ups. University of Cambridge Institute for Manufacturing, 42. Retrieved from http://www.ifm.eng.cam.ac.uk/ uploads/Research/CTM/Resources/12_01_dee_minshall.pdf

Aaboen, L. (2009). Explaning incubators using firm analogy. Technovation, 29, 657-670. http://dx.doi.org/10.1016/j.technovation.2009. 04.007

Bergek, A. and C. Norrman. (2008). Incubator best practice: a framework. Technovation, 28, 20-28. http://dx.doi.org/10.1016/j. technovation.2007.07.008

Chen, C.-J. (2009). Technology commercialization, incubator and venture capital, and new venture performance. Journal of Business research, 62, 93-103. http://dx.doi.org/10.1016/j.jbusres.2008.01.003

Kemp, Ph. (2011). Exploring a model for technology business incubation for business start-ups in Australia. Small Enterprise Research, 2, 155-157. http://dx.doi.org/10.5172/ser.2011.18.2.155

Lilai, X. (2010). Business incubation in China: Effectiveness and perceived contributions to tenant enterprises. Management Research Review, 1, 90 - 99. http://dx.doi.org/10.1108/01409171011011599 